\title{
BEYOND THE ROE DEBATE: JUDICIAL EXPERIENCE WITH THE 1980's “REASONABLENESS” TEST
}

\author{
Daniel A. Farber* and John E. Nowak**
}

GHOULD Roe v. Wade ${ }^{1}$ be overruled? Your answer to that question may depend in some measure on which "Roe v. Wade" you mean. Of course, there was only one Roe v. Wade opinion. But, in fact, there are two different approaches to imterpreting and applying Roe. One interpretation calls for strict judicial review of all regulations imposing even the slightest impediment to abortion services. That approach may have been the intent of Justice Blackmun, the author of Roe v. Wade, and of a majority of the Justices in the early to mid-1970's. As we will show, however, an alternative interpretation of Roe has held sway with a majority of Justices during the 1980's. Under this more recent interpretation, women have a right to an abortion subject to certain types of "reasonable" regulations.

Unfortunately, like many participants in the abortion debate, the Justices often have remained mired in 1973, as if neither abortion law nor other constitutional doctrines have changed since they handed down Roe. Webster v. Reproductive Health Services, ${ }^{2}$ the most recent round in the judicial abortion debate, exemplifies the staleness of the discussion. In his plurality opinion, Chief Justice Rehnquist sharply criticized Roe for providing an unduly rigid legal framework, one ripe for reconsideration because it was "unsound in principle and unworkable in practice." 3 In dissent, Justice Blackmun castigated

* Henry J. Fletcher Professor of Law, University of Minnesota.

** Professor of Law, University of Illinois. We thank Phil Frickey and Suzanna Sherry, Professors at the University of Minnesota, for their comments on an earlier draft; Cheryl Nyberg and Jane Williams, Reference Librarians at the University of Illinois, for their assistance with our computer searches for lower court abortion cases; and Carolyn BrueLegried for her research assistance.

1410 U.S. 113 (1973).

2109 S. Ct. 3040 (1989).

3 Id. at 3056 (plurality opinion) (quoting Garcia v. San Antonio Metro. Transit Auth., 469 U.S. 528, 546 (1985)). Chief Justice Rehnquist also argued that the state's interest in preserving potential human life exists from the beginning of pregnancy and may be compelling before viability. Id. at 3057 (plurality opinion). For reasons explained in a previous article authored by one of us, we do not believe that this interest is strong enough to justify a ban on 
Rehnquist for avoiding the "true jurisprudential debate underlying this case," namely, whether the "right to privacy" is entitled to constitutional protection. ${ }^{4}$

We believe that both Justices' arguments are anachronistic. The rigid framework created by Roe and attacked by Rehnquist has long since vanished. A survey of recent lower court opinions demonstrates that the 1980's approach is eminently workable. We believe that Blackmun, too, was refighting bygone battles. The jurisprudential dispute over the existence of fundamental rights continues to engage scholars, but it is no longer a matter of urgent concern for the Court. ${ }^{5}$ Both developments-the post-1973 modification of the Roe framework and the fading of the jurisprudential dispute-now open the door to a constructive judicial resolution of the abortion issue.

Among those Justices who have questioned Roe, all but Justice Scalia have demonstrated some inchination toward finding a compromise position. ${ }^{6}$ We beheve that the elements of such a doctrinal compromise already have been hammered out, but not articulated, in a series of cases in the 1980's. Whatever Roe v. Wade originally may have meant in Justice Blackmun's mind, it now encompasses a much more flexible approach to abortion.

The touchstone of this new approach is reasonableness. A Restatement of the Law of Abortion, if the ALI were to attempt such a project, would distill something like the following rules from the Court's recent holdings:

A state abortion regulation will be upheld if it is a reasonable effort to (1) protect the woman's health, (2) ensure that minors make responsible decisions, or (3) protect a viable or possibly viable fetus. A health regulation may not unduly burden the right to abortion. Statutes protecting possibly viable fetuses must not be so vague as to deter abortions of nonviable fetuses and must allow abortions when a physician finds a significant threat to the life or health of the woman. So long as it does not impose a significant barrier to, or a penalty for, abortions,

early abortions. See Farber, Legal Pragmatism and the Constitution, 72 Minn. L. Rev. 1331, 1370-72 (1988).

4109 S. Ct. at 3072.

5 The rejection of the Bork nomination also seems to reflect widespread public agreement with the fundamental rights doctrine. See N.Y. Times, Oct. 7, 1987, at B10, col. 1.

6 See Webster, 109 S. Ct. at 3064-67 (Scalia, J., concurring) (taking lone position that the Court should have used the issues in Webster to overrule Roe expressly). 
the state may take other steps to discourage women from choosing to have an abortion.

This "restatement" admittedly describes a more limited right to abortion than that expressed by the Roe majority opinion. Even if one would favor the more "absolute" right endorsed in Roe, this restated abortion principle is the one that exists today. It is the only principle that can unify the holdings, if not the Justices' opinions, of the 1980's abortion cases. The reasonableness approach provides substantial protection for a woman's right to control her body. It is this limited, yet substantial, right that should be the focus of debate when the Court considers whether or not to overturn earlier abortion rulings.

Our thesis is that the Court should endorse openly the "rule of reason" for abortion regulations and, therefore, that it need not and should not overrule Roe v. Wade. We will present our argument in three stages. First, we will describe the reasonableness approach and how it was established by the holdings of the Supreme Court in the late 1970's and early 1980's. Second, we will survey the decisions of the states' highest courts and of the United States Courts of Appeals during the mid-1980's. This survey will demonstrate that the lower courts have successfully applied the reasonableness principle. Finally, we will explain why the Court should consider the older jurisprudential debate about the legitimacy of Roe irrelevant when it next considers the question of protecting the right to have an abortion subject to reasonable medical regulations.

\section{The Evolution of the Reasonableness Test}

Writing in the early 1970's, Alexander Bickel was sharply critical of Roe v. Wade. ${ }^{7} \mathrm{He}$ considered Roe a reversion to the Court's abuse of substantive due process in the Lochner era, in part because of its inflexibility. The Roe opinion precluded any regulation of abortions during the first trimester and greatly restricted health regulations of other abortions. ${ }^{8}$ "The state regulates and licenses restaurants and pool halls and Turkish baths and God knows what else in order to protect the public," Bickel observed, "why may it not similarly regulate and license abortion clinics, or doctors' offices where abortions

7 A. Bickel, The Morality of Consent 27-29 (1975).

8 See Roe, 410 U.S. at 164. 
are to be performed?"9

Professor Bickel based his assessment on a straightforward reading of Roe. And it may well have been an accurate assessment of Justice Blackmun's intention, given that he has been a frequent dissenter in the more recent abortion cases. ${ }^{10}$ Justice Blackmun's majority opinion in Roe seemed to create a virtually unlimited right to an abortion before the third trimester. ${ }^{11}$ The majority opinion in Roe seemed irreconcilable with Chief Justice Burger's concurrence in Doe v. Bolton, which denied that the Court had created a right to "abortions on demand." 12

Lower courts initially took Justice Blackmun's opinion hiterally and invalidated all regulations of first trimester abortions and most regulations of second trimester abortions. ${ }^{13}$ The Court soon made it clear, however, that Roe's statement about the states' inability to regulate first trimester abortions should not be taken literally. By the mid1970's, the Court had upheld laws prohibiting non-physicians from performing abortions ${ }^{14}$ and laws requiring hospitals to keep confiden-

9 A. Bickel, supra note 7, at 27.

10 See, e.g., Webster v. Reproductive Health Servs., 109 S. Ct. 3040, $3067-79$ (1989) (Blackmun, J., concurring in part and dissenting in part); Planned Parcnthood Ass'n v. Ashcroft, 462 U.S. 476, 494-504 (1983) (Blackmun, J., concurring in part and dissenting in part).

11 See Roe, 410 U.S. at 164:

(a) For the stage prior to approximately the end of the first trimester, the abortion decision and its effcctuation must be left to the medical judgment of the pregnant woman's attending physician.

(b) For the stage subsequent to approximately the end of the first trimester, the State, in promoting its interest in the health of the mother, may, if it chooses, regulate the abortion procedure in ways that are reasonably related to maternal health.

12 Doe v. Bolton, 410 U.S. 179, 207-08 (1973) (Burger, C.J., concurring).

13 See, e.g., Friendship Medical Center, Ltd. v. Chicago Bd. of Health, 505 F.2d 1141 (7th Cir. 1974), cert. denied, 420 U.S. 997 (1975) (reversing denial of injunction against enforcement of city's health regulations that sought to regulate abortion facilities during the first trimester on the grounds that they contravened the plain language of Roe); Word v. Poelker, 495 F.2d 1349 (8th Cir. 1974) (relying on the plain language of Roe and Doe in declaring unconstitutional a St. Louis ordinance requiring abortion clinics seeking to perform abortions other than to save the pregnant woman's life to obtain a permit); Hallmark Clinic v. North Carolina Dep't of Human Resources, 380 F. Supp. 1153 (E.D.N.C. 1974), aff'd, 519 F.2d 1315 (4th Cir. 1975) (enjoining enforcement of state's regulation of first trimester abortion facilities from any licensing requirement that did not apply to modical facilities generally).

14 Connecticut v. Menillo, 423 U.S. 9 (1975) (per curiam) (holding that a state can constitutionally punish a non-physician for performing an abortion). 
tial abortion records. ${ }^{15}$ Moreover, the Court held in 1983, states may require pathologists' reports for all abortions, ${ }^{16}$ including first-trimester abortions, even though the dissent complained that this requirement could raise the cost of an abortion by twenty percent. ${ }^{17}$ By the mid-1980's, a more flexible judicial standard that accommodated reasonable government regulations of abortions clearly had replaced the rigid trimester approach of the Roe opinion.

By 1986, it was quite literally "black letter" or "hornbook" law that in pre-viability abortions Roe requires strict scrutiny only to determine if the regulation in question is a reasonable health regulation. ${ }^{18}$ As a complement to this rule, the Court on vagueness grounds also requires regulations, especially those with crimmal penalties, to give doctors very clear notice as to whether or not an operation is permissible. ${ }^{19}$ Strict scrutiny apphes only to laws focused on abortions; doctors must follow vahd general regulation of medical procedures when performing abortions. ${ }^{20}$

In the 1980's, states also could regulate abortions to protect a possibly viable fetus as long as two conditions were met: first, the statute could not be so vague as to deter abortions of nonviable fetuses, and, second, the government had to allow an abortion if the doctor found a significant threat to the preguant woman's life or health. ${ }^{21}$ This reasonableness approach gives siguificant weight to the state's interest in protecting potential life. For example, the state may require that, during the abortion of a viable fetus, a second doctor be present to provide medical care for the child. ${ }^{22}$

The Court, admittedly without a majority opinion, used the same type of reasonableness review for laws regulating abortions for

15 Planned Parenthood v. Danforth, 428 U.S. 52, $79-81$ (1976) (upholding record-keeping requirements even though they applied to first trimester abortions).

16 Planned Parenthood Ass'n v. Ashcroft, 462 U.S. 476, 486-90 (1983).

17 Id. at $498 \mathrm{n.4}$ (Blackmun, J., concurring in part and dissenting in part).

18 J. Nowak, R. Rotunda \& J. Young, Constitutional Law 698 (3d ed. 1986).

19 Id. at 703.

20 Id. at 699.

21 This point also should have been understood by all students of the law since it was also "black letter law" by the mid-1980's. Id. at 697, 700; J. Nowak, R. Rotunda \& J. Young, Constitutional Law 62 (3d ed. Supp. 1988).

22 Planned Parenthood Ass'n v. Ashcroft, 462 U.S. 476, 482-86 (1983). 
minors. ${ }^{23}$ Thus, an unemancipated minor's abortion can be delayed until her parents are notified, as long as the delay does not create any serious health risks. ${ }^{24}$ The Court also has established clear rules regarding parental consent. A state law requiring parental consent is valid if, but only if, it allows the minor to obtain an abortion with the consent of a juvenile court judge. The judge must determine if the mimor is mature enough to make the decision herself or, alternatively, if the abortion is in her best interests. These rules were established by Justice Powell's 1979 plurality opinion in Bellotti v. Baird (Bellotti $I I),{ }^{25}$ in which the Supreme Court invalidated a parental consent requirement, and by Planned Parenthood Association, Inc. v. Ashcroft, ${ }^{26}$ in which the Court upheld a parental consent law that included a judicial bypass procedure complying with the principles announced by Justice Powell in Bellotti II. The Court would uphold such a parental consent law so long as the procedure "does not effectively cut off the right to an abortion through delay."27

In short, the rigid framework of the Roe opinion is long gone. Today, "Roe v. Wade" really stands for a much more flexible approach. Just as it has done in antitrust law, the Court has replaced a set of per se rules with the "rule of reason."

\section{DOES THE "Rule OF ReAson" WORK?}

In his plurality opinion in Webster, Chief Justice Rehnquist coinplained of the unworkability of the Roe approach. To assess this complaint, we examined the published abortion decisions in the United States Courts of Appeals and the states' highest courts between July

23 As Justice Blackmun has argued, these decisions are probably inconsistent with the Roe opinion. Ashcroft, 462 U.S. at 503-04 (Blackmun, J., concurring in part and dissenting in part).

${ }^{24}$ See H.L. v. Matheson, 450 U.S. 398, 411-13 (1981); J. Nowak, R. Rotunda \& J. Young, supra note 18 , at $706-09$.

25443 U.S. 622 (1979) (plurality opinion of Powell, J., joined by Burger, C.J., and Stewart and Rehnquist, JJ.). The Powell plurality opinion stated in a footnote that if the child received support from a single parent, the mutual decision of the child and her single parent, in a state that required the consent of both parents, "should be given great, if not dispositive weight." Id. at 649 n.29. Justice Rehnquist, in a separate opinion, indicated that he would be willing to reconsider whether or not a minor has a right to an abortion but, until a majority of the Justices were willing to reconsider that issue, he would agree with Justice Powell. 443 U.S. at 651-52 (Rehnquist, J., concurring).

26462 U.S. 476, 490-93 (1983).

27 J. Nowak, R. Rotunda \& J. Young, supra note 18, at 705. 
1, 1986 and July 1,1989..$^{28}$ We chose these dates to look for the problems, if any, that the courts were having in applying the abortion rules established by the Court through the mid-1980's. July 1, 1986, marks the end of the Term in which the Court decided Thornburgh $v$. American College of Obstetricians and Gynecologists. ${ }^{29}$ By then, as stated earlier, everyone should have understood that the reasonableness approach was "black letter law." July 1, 1989, is almost the "eve" of Webster, the latest Supreme Court abortion decision.

\section{A. The Experience of the State Courts}

Between July 1, 1986 and July 1, 1989, the highest courts of the fifty states and of the District of Columbia decided eleven cases that arguably could be called abortion decisions. We exempted from this compilation those cases that involved conflicts between proabortion and antiabortion groups, such as defamation actions brought by a member of one group against another or trespass actions brought against antiabortion protesters. ${ }^{30}$ Similarly excluded are abortion malpractice and "wrongful birth" cases. ${ }^{31}$ Of the remaining eleven cases, only two involved attacks on statutes that regulated abortions.

In Ex parte Anonymous, ${ }^{32}$ the Supreme Court of Alabama unanimously upheld a parental consent statute that conformed to Bellotti II and Ashcroft. Without dissent, the Alabama judges also found that the particular minor was not mature enough to make her own decision. ${ }^{33}$ They ruled six to three, however, that the abortion had not been shown to be against her best interest. ${ }^{34}$ Thus, although the Alabama justices divided on the application of the statute, they appar-

$28 \mathrm{We}$ did not attempt to survey opinions from the federal district courts and lower state courts or unpublished opinions from any jurisdiction.

29476 U.S. 747 (1986) (affirming Third Circuit decision enjoining enforcement of Pennsylvania's 1982 Abortion Control Act and invalidating "informed consent" provisions).

30 See, e.g., Moffatt v. Brown, 751 P.2d 939 (Alaska 1988) (physician denied relief in libel action brought against an antiabortion group); State ex rel. Tilford v. Crush, 39 Ohio St. 3d 174, 529 N.E.2d 1245 (1988) (per curiam) (antiabortion picketer denied writ of prohibition that would have nullified injunction against picketing outside a Cincinnati abortion clinic).

31 See, e.g., Sherman v. District of Columbia Bd. of Medicine, 557 A.2d 943 (D.C. 1989) (malpractice and loss of medical license case relating to abortion services); C.S. v. Nielson, 767 P.2d 504 (Utah 1988) ("wrongful" pregnancy and birth after sterilization procedure).

32531 So. 2d 901 (Ala. 1988) (per curiam).

33 Id. at 905.

34 Id. at 907-09. 
ently had no problem in understanding and applying the Bellotti II/ Ashcroft doctrine.

Similarly, the Colorado Supreme Court encountered no difficulty in upholding an antiabortion amendment to the state constitution. Urbish v. Lamm $^{35}$ involved a provision of the Colorado Constitution that prohibited most public funding of abortions. ${ }^{36}$ The Colorado Supreme Court, in a unanimous en banc opinion, disposed of the federal constitutional issues im a footnote, correctly concluding that the state provision did not conflict with the right of women to have abortions as defined by the Supreme Court in the 1980's. ${ }^{37}$

Only these two cases involved any question of the validity of an abortion statute. The other nine state cases concerned the role of third parties in the abortion decision. In two cases the Indiana Supreme Court, with only one dissent, denied an injunction sought by the father of a fetus to prevent its abortion. ${ }^{38}$ In a separate case, decided with a four paragraph summary ruling, the same court found that a state statute entitled a minor to an abortion because her mother had consented, even though her mother did not, in fact, have legal custody of the mimor: ${ }^{39}$ In two cases involving legally incompetent women, courts had to decide whether or not to order an abortion. In both cases, the Suprenie Court's definition of a woman's right to privacy was considered, but Roe had little to do with the outcomes. ${ }^{40}$

35761 P.2d 756 (Colo. 1988) (en banc).

36 Colo. Const. art. V, $\S 50$.

37761 P.2d at 760 n.2. The Supreme Court, in decisions rendered in 1977 and 1980, had held that a governmental refusal to fund abortion services for indigent women violated neither the equal protection nor the due process clause, even when the denial related to medically necessary abortions and even when the government provided economic subsidies for child birth services. Williams v. Zbaraz, 448 U.S. 358 (1980); Harris v. McRae, 448 U.S. 297 (1980); Poelker v. Doe, 432 U.S. 519 (1977); Maher v. Roe, 432 U.S. 464 (1977); Beal v. Doe, 432 U.S. 438 (1977). These decisions may have been inconsistent with the "original intent" of the Roe v. Wade opinion, given that Justice Blackmun, the author of Roe, dissented in these cases. See J. Nowak, R. Rotunda \& J. Young, supra note 18, at 709-11.

38 Conn v. Conn, 526 N.E.2d 958 (Ind. 1988) (adopting the opinion and judgment in Conn v. Conn, 525 N.E.2d 612 (Ind. App. 1988)), cert. denied, 109 S. Ct. 391 (1988); Doe v. Smith, 527 N.E.2d 177 (Ind. 1988).

39 In re P.R., 497 N.E.2d 1070 (Ind. 1986). Although a judicial order had placed the minor under the wardship of the County Department of Public Welfare, which had not consented to the abortion, the order did not completely terminate the mother's parental rights. Id. at 1070 .

40 The District of Columbia Court of Appeals, in In re A.C., 533 A.2d 611 (D.C. 1987), vacated, 539 A.2d 203 (D.C. 1988) (per curiam), denied a request to stay a superior court order permitting a Caesarean section operation to be performed on a terminally ill woman. The court found that the interest in preserving the viable fetus's life justified overriding the 
The remaining four decisions that might arguably be termed "abortion cases" arose from disputes about abortion, but did not directly relate to the regulation of abortion rights. ${ }^{41}$

\section{B. Decisions of the United States Courts of Appeals}

It appears to be more popular to attack abortion regulations in federal rather than state court. Ten federal appellate decisions involved the constitutionality of state abortion regulations. The Supreme Court granted certiorari on four of the ten cases. ${ }^{42}$ Additionally, the courts of appeals decided several other cases involving abortionrelated topics. ${ }^{43}$

\section{1. $1986-87$}

In the three abortion cases decided in 1986 and 1987, the courts of appeals each time invalidated state abortion regulations. In Margaret S. v. Edwards, ${ }^{44}$ the United States Court of Appeals for the Fifth Circuit invalidated a Louisiana law requiring that doctors advise women

woman's decision to refuse medical treatment. The court initially decided the case even though the order had been complied with, the operation had been performed, and both the mother and child had died soon afterwards. The opinion was later withdrawn.

Because courts have on occasion ordered medical treatment for mentally retarded persons, it is difficult to determine if Roe v. Wade is critical to the Rhode Island Supreme Court's finding that a trial judge properly authorized an abortion for a profoundly retarded young woman whose pregnancy was brought about by a sexual assault. The supreme court in In re Doe, 533 A.2d 523 (R.I. 1987) (per curiam), upheld the trial court's selection of a "surrogate decisionmaker" to make the decision regarding the retarded young woman's pregnancy and to override objections from the biological mother of the mentally retarded pregnant child, in part because the mother had had only "slight and sporadic" contact with her retarded daughter over a period of several years. Id. at 526-27.

41 In one case, the Connecticut Supreme Court held that attorney's fees were not warranted, although attorneys representing a class of indigent women were successful in enjoining the state from restricting payments for abortions to patients eligible for state medical assistance. Doe v. Heintz, 204 Conn. 17, 526 A.2d 1318 (1987). Three state supreme courts examined the procedures required to enact a statute or constitutional amendment by referendum, when the referendum related to restrictions on public funding for abortions. In re Proposed Constitutional Amendment Under the Designation "Pregnancy," 757 P.2d 132 (Colo. 1988) (en banc); Frey v. Department of Management and Budget, 429 Mich. 315, 414 N.W.2d 873 (1987); State ex rel. Bunn v. Roberts, 302 Or. 72, 726 P.2d 925 (1986) (en banc).

42 The Supreme Court agreed to review all four decisions of the United States Courts of Appeals regarding abortion regulations that were rendered in 1988. See infra notes 49-62 and accompanying text. One of these cases has been settled out of court. See infra note 60 and accompanying text.

43 See infra note 71 .

44794 F.2d 994 (5th Cir. 1986). 
of their options regarding fetus burial or cremation. The same decision also invahidated a prohibition on fetal experimentation for being unconstitutionally vague. ${ }^{45}$ The first ruling was a straightforward application of Akron. ${ }^{46}$ Also on the basis of Akron, the United States Court of Appeals for the Sixth Circuit invalidated a statute regulating the disposal of fetal remams for being unconstitutionally vague. ${ }^{47}$ Finally, the United States Court of Appeals for the Third Circuit ruled that laws limiting access to abortions for inmates at a county correctional facility violated both $R o e$ and the eighth amendment. ${ }^{48}$

\section{1988}

The Supreme Court has granted certiorari for all four of the federal appellate rulings decided in 1988, although one case has since been settled. ${ }^{49}$

In Webster v. Reproductive Health Services, ${ }^{50}$ the Supreme Court reversed the Eighth Circuit ${ }^{51}$ on four points. First, the Court found that the preamble to a Missouri statute declaring that life begins at conception as yet had had no significant effect on abortion rights and

45 Id. at 998-99.

46 In Akron, the Court struck down a requirement that doctors, rather than other medical professionals, provide women with an inflexible list of information about abortions as part of a consent requirement. The Supreme Court also invalidated a statute requiring physicians, after performing an abortion, to dispose of fetal remains in a "humane and sanitary manner." City of Akron v. Akron Center for Reproductive Health, Inc., 462 U.S. 416, 451 (1983).

47 Planned Parenthood Ass'n v. Cincinnati, 822 F.2d 1390 (6th Cir. 1987). The statute was quite similar in substance to the one invalidated in Akron.

48 Monmouth County Correctional Institutional Inmates v. Lanzaro, 834 F.2d 326 (3d Cir. 1987), cert. denied, 486 U.S. 1006 (1988). The regulations invalidated by the Third Circuit required inmates wishing to have an abortion to obtain both a release from the correctional facility and their own financing for the abortion.

As long as abortions are lawful in a state, a question exists as to whether or not a state's refusal to fund abortions for female prisoners violates the cruel and unusual punishment clause. Moreover, because the eighth amendment protects prisoners from "deliberate indifference to serious medical needs," see Estelle v. Gamble, 429 U.S. 97, 104 (1976), overruling $R o e$ would not eliminate the need for a judicial ruling on abortions for pregnant prisoners. The United States Court of Appeals for the Eighth Circuit explicitly avoided the former issue in Reproductive Health Serv. v. Webster, 851 F.2d 1071, 1084 n.17 (8th Cir. 1988), rev'd on other grounds, 109 S. Ct. 3040 (1989).

49 We are counting Hodgson v. Minnesota, 853 F.2d 1452 (8th Cir. 1988), cert. granted, 109 S. Ct. 3240 (1989), as one case even though it appears as two separate, but combined, cases (Sup. Ct. No. 88-1125 and No. 88-1309) on the Supreme Court's docket for the October 1989 Term.

50109 S. Ct. 3040 (1989).

51 Reproductive Health Serv. v. Webster, 851 F.2d 1071 (8th Cir. 1988). 
therefore did not present a ripe controversy. ${ }^{52}$ Second, the Court upheld the statutory prohibition of the use of public facilities or employees to perform abortions, noting that nothing in the Constitution mandated either a state's participation in the business of providing abortions or a right of access to public facilities by private physicians and their patients seeking abortions. ${ }^{53}$ Third, the Court unanimously held the prohibition against public funding of abortion counseling to be a moot issue. ${ }^{54}$ And finally, accepting the state's interpretation, the Court left standing a statutory requirement that physicians conduct certain viability tests if they believed the tests to be necessary to make a viability determination. ${ }^{55}$ Perhaps the lesson that federal appeals court judges should take from Webster is that courts should be more accepting of the state's interpretation of its own abortion laws. Unlike the Eighth Circuit, the majority of the Justices were willing to defer to the state's interpretation of its statute. Given the state's interpretation, the Missouri statute clearly was valid under the reasonableness approach.

Two other 1988 decisions relate to parental notification and consent requirements for abortions sought by minors. The Supreme Court will review both of these decisions in its October 1989 Term. In one decision, the Eighth Circuit upheld a statute requiring a forty-eight hour delay after parents are notified of a minor's intent to have an abortion. ${ }^{56}$ The Supreme Court has not ruled previously on the validity of a post notification waiting period. Nevertheless, application of the reasonableness test should not be difficult. The question is whether or not the law reasonably promotes family decisions by

52 Webster, $109 \mathrm{~S}$. Ct. at 3049-50.

53 Id. at 3052.

54 Id. at 3053-54. Plaintiffs' decision not to continue seeking declaratory relief with respect to the prohibition of abortion counseling mooted any dispute regarding its constitutionality. Id. at 3053.

55 Id. at 3054-58. The state asserted that the statute did not require these tests for all abortions performed after 20 weeks of pregnancy. Id. at 3054 . The plaintiffs did not appeal the district court's ruling upholding the statute's presumption that all 20-week fetuses are viable. See id. at 3061 (O'Connor, J., concurring).

56 Hodgson v. Minnesota, 853 F.2d 1452 (8th Cir. 1988) (en banc). The court also upheld a requirement that both parents be notified, even if only one has custody. Id. at 1462-63. Finally, the Eighth Circuit held that the parental notification provision needed to have a judicial bypass. Id. at 1456-57. For an extensive discussion of the facts in Hodgson, see Pine, Speculation and Reality: The Role of Facts in Judicial Protection of Fundamental Rights, 136 U. Pa. L. Rev. 655, 677-97 (1988). 
allowing time for consultation, or whether the delay creates a health risk or effectively eliminates the ability to obtain an abortion without parental consent. ${ }^{57}$ In the other decision, the Sixth Circuit held that a parental notification requirement was unconstitutional because the judicial "bypass procedure" was cumbersome and slow. ${ }^{58}$ Identifying the governing principles of cases like H.L. v. Matheson, ${ }^{59}$ Bellotti II, and Ashcroft appeared to present no difficulty for the Sixth Circuit. In its review of this court of appeals decision, the Supreme Court merely will have to decide if it agrees with the Sixth Circuit's assessment of the unreasonableness of the statute.

The final case originally scheduled for Supreme Court review, although it has since been settled, is the Seventh Circuit's decision in Ragsdale v. Turnock. ${ }^{60}$ In Ragsdale, the Seventh Circuit struck down an Illinois law requiring that abortions be performed in hospitals or ambulatory surgical treatment centers. According to the court, the Illinois regulations were invalid because they raised the cost of a first trimester abortion by twenty-five to forty dollars and might have limited the number of clinics and facilities performing abortions. ${ }^{61}$ The

57 In a case predating the time period of our survey, the United States Court of Appeals for the Seventh Circuit ruled that a state statute requiring a minor to wait 24 hours after the notification of her parents violated the minor's constitutional right to privacy. Zbaraz v. Hartigan, 763 F.2d 1532 (7th Cir. 1985). An equally divided Supreme Court affirmed the Seventh Circuit's decision at a time when there were only eight Justices. Hartigan v. Zbaraz, 484 U.S. 171 (1987) (per curiam). Assuming that Justice Kennedy would vote to approve such a law, the Supreme Court's affirmance in Zbaraz involves nothing more than the Ashcroft dissenters taking advantage of the even number of Justices voting in the case.

The notification statute the Supreme Court approved in H.L. v. Matheson, 450 U.S. 398 (1981), did not impose a fixed waiting period following notification of the minor's parents. Any notification requirement, however, would result in delaying somewhat the minor's abortion. Thus, if the Seventh Circuit had been true to the 1980's approach to the abortion right, as explained in cases like Bellotti II, H.L. v. Matheson, and Ashcroft, it probably would have upheld a statute requiring a brief, fixed waiting period following notification of the minor's parents as long as: (1) the waiting period was rcasonably related to the interest in deferring such decisions to the family unit, the same interest that supported the H.L. $v$. Matheson decision, and (2) the law did not create unreasonable delay so as to make the abortion procedure either more dangerous for the pregnant minor or more likely to involve a viable fetus.

58 Akron Center for Reproductive Health v. Slaby, 854 F.2d 852 (6th Cir. 1988), prob. juris. noted sub nom. Ohio v. Akron Center for Reproductive Health, 109 S. Ct. 3239 (1989).

59450 U.S. 398 (1981).

60841 F.2d 1358 (7th Cir. 1988), jurisdiction postponed, 109 S. Ct. 3239 (1989), joint motion to defer further proceedings granted, $110 \mathrm{~S}$. Ct. 532 (1989). See generally N.Y. Times, Nov. 23, 1989, at A1, col. I (describing details of settlement).

61841 F.2d at 1370 . 
court's analysis is debatable for two reasons. First, the Seventh Circuit refused to accept the state government's assertion that the medical regulations did not apply to first trimester abortions. ${ }^{62}$ And second, the Seventh Circuit's detailed analysis of the medical basis for the regulations protecting the health of women may be mconsistent with the reasonableness approach that the Supreme Court has used in the 1980's. ${ }^{63}$ Nevertheless, the issues in this case were far from intractable. The Supreme Court would have needed only to determine if the health regulations at issue were reasonably related to the protection of the pregnant woman's health.

\section{1989}

There were three decisions in the first six months of 1989 concerning abortion regulations. In Planned Parenthood League v. Bellotti, ${ }^{64}$ the United States Court of Appeals for the First Circuit found that a state statute requiring the consent of a pregnant minor's parents before performing an abortion was valid because it included the type of bypass procedure that had been approved by the Supreme Court's plurality decisions in the 1980's. ${ }^{65}$ In Women's Health Center v. Webster, ${ }^{66}$ the Eighth Circuit, employing the Supreme Court's 1980's reasonableness approach, upheld a statute requiring physicians who wanted to perform abortions to have surgical privileges at hospitals

62 Id. at $1368-69$.

63 See, e.g., Simopoulos v. Virginia, 462 U.S. 506, 519 (1983) ("[T] that second-trimester abortions be performed in licensed clinics appears to comport with accepted medical practice, and leaves the method and timing of the abortion precisely where they belong-with the physician and the patient."); Akron v. Akron Center for Reproductive Health, 462 U.S. 416, 429 n.11 (1983) ("Where the State adopts a health regulation governing the performance of abortions during the second trimester, the determinative question should be whether there is a reasonable medical basis for the regulation.").

The Seventh Circuit conceded that "[a] number of the regulations involved may well pass muster under the less stringent standard of review applied to state regulation of second trimester abortions." Ragsdale, 841 F.2d at 1368 n.8. Citing Simopoulos, the court observed that "some licensing of facilities performing second trimester abortions would be permissible." Id. at 1369 n.8. The court concluded, however, that this "nettlesome" issue was not before it, as the regulations at issue in Ragsdale made no distinction between first and second trimester abortions. Id. at 1368-69.

64868 F.2d 459 (1st Cir. 1989).

65 Id. at 469.

66871 F.2d 1377 (8th Cir. 1989). 
offering gynecological or obstetrical care. ${ }^{67}$

The third decision in the spring of 1989 implicated both substantive due process and first amendment concerns. In Massachusetts v. Secretary of Health and Human Services, ${ }^{68}$ the First Circuit initially invalidated federal regulations banning recipients of federal funds from engaging in abortion-related activities, regardless of whether those activities involved federal funds. ${ }^{69}$ Before withdrawing its opinion pending disposition of motions for rehearing, the court of appeals found that this restriction on privately funded abortion-related activities violated $R o e$, even under the reasonableness approach. The court also held that the attempt to suppress pro-choice advocacy by private groups receiving some federal funds violated the first amendment. Although difficult issues are presented by this case, they involve the proper application of the unconstitutional conditions doctrine ${ }^{70}$ rather than any particular obscurity in abortion law.

In addition to these ten cases, from 1986 to 1989 the courts of appeals also dealt with a number of cases that might not have existed but for the Supreme Court's establishment of a right to privacy, even though they were not truly abortion regulation cases. ${ }^{71}$ Most of the

67 The Eighth Circuit ruled that the physician in the case lacked standing to challenge the statute's "antidiscrimination" provision, which prohibited discrimination against any individuals based on their refusal to participate in abortion services. Id. at 1383-84.

68 No. 88-1279 (1st Cir. May 8, 1989), op. withdrawn, 873 F.2d 1528 (ist Cir. 1989).

69 See 42 C.F.R. $§ \S 59.8-10$ (1988). The regulations had been promulgated by the Secretary of Health and Human Services under Title X of the Public Health Services Act, 42 U.S.C. $\S 300 \mathrm{a}-6$ (1982).

70 For an examination of theories regarding how the constitutionality of conditions on government spending should be analyzed, see Rosenthal, Conditional Federal Spending and the Constitution, 39 Stan. L. Rev. 1103 (1987); Sullivan, Unconstitutional Conditions, 102 Harv. L. Rev. 1415 (1989). See Westen, Incredible Dilemmas: Conditioning One Constitutional Right on the Forfeiture of Another, 66 Iowa L. Rev. 741 (1981).

71 Among the half-dozen or more cases falling into this category are cases involving: (1) questions regarding attorney's fees to plaintiffs who successfully challenge a state abortion statute, see Charles v. Daley, 846 F.2d 1057 (7th Cir. 1988), cert. denied, 109 S. Ct. 3214 (1989) ("follow-up" decision to Diamond v. Charles, 476 U.S. 54 (1986)); (2) questions regarding state-required payments for family planning services under federal medicaid statutes and regulations, see Planned Parenthood Ass'n v. Dandoy, 810 F.2d 984 (10th Cir. 1987); (3) state claims for reimbursement from the Department of Health and Human Services for providing court-ordered medicaid abortions, see Massachusetts v. Departmental Grant Appeals Bd., 815 F.2d 778 (1st Cir. 1987); (4) the constitutionality of a "feticide" statute criminalizing harm to a pregnant woman that results in the killing of a viable fetus, see Smith v. Newsome, 815 F.2d 1386 (11th Cir. 1987); (5) a challenge by a physician to zoning ordinances preventing him from opening an abortion clinic, see Haskell v. Washington 
issues in these cases would survive even if Roe were overruled. ${ }^{72}$

On the one hand, it is possible to argue that any area of the law in which the Supreme Court reviews almost half of the circuit court decisions must have something wrong with it. On the other, the Court's abortion decisions have not created an obvious burden on the lower courts, and the reasonableness standard usually has proved easy to apply.

\section{The IRRElevance of The Fundamental Rights Debate}

The workability issue may seem mundane compared with the grand philosophical issues that have dommated the scholarly debate about abortion. Although that debate has obvious intellectual importance, it may be less significant to the choices now facing the Court. Thus, there is something to be said for Rehnquist's reluctance in Webster "to elaborate the abstract differences between a 'fundamental right' to abortion, . . . a 'limited fundamental constitutional right,' . . . or a liberty interest protected by the Due Process Clause."73

Roe sparked a heated jurisprudential debate about judicial review that contmues to this day. Because the Court's action was so sweeping, Roe seemed to raise especially basic questions of institutional legitimacy. Unlike Griswold, ${ }^{74}$ in which the Court struck down an aberrational ban on birth control, the Roe Court invalidated every abortion statute in the country. Because this pronouncement seemed to threaten a massive intrusion on legislative decisionmaking, it therefore required an extraordinarily powerful justification. One reason why the judicial debate has been so heated is the perception that deep

Township, 864 F.2d 1266 (6th Cir. 1988); and (6) challenges, on right to privacy grounds, by Medicare recipients to Social Security Act regulations restricting their ability to hire additional physicians at their own expense, see New York Statc Ophthalmological Soc'y v. Bowen, 854 F.2d 1379 (D.C. Cir. 1988), cert. denied, 109 S. Ct. 2448 (1989). The number of cases with "abortion-related issues" in the courts of appeals would rise if we included first amendment challenges to restrictions on the activities of antiabortion protestors.

72 For example, overruling Roe $v$. Wade would not affect the number of first amendment cases that arise because of the abortion issues. Right-to-privacy rulings only affect which group is more likely to be protesting, getting arrested, and challenging convictions under the first amendment. See also supra note 48 .

73 Webster v. Reproductive Health Servs., 109 S. Ct. 3040, 3058 (1989) (plurality opinion of Rehnquist, C.J., joined by White and Kennedy, JJ.) (citations omitted). To the extent the distinction is relevant, we believe that abortion is a fundamental right. See Farber, supra note 3 , at $1366-69$.

74 Griswold v. Connecticut, 381 U.S. 479 (1965). 
issues of constitutional theory are at stake. As we noted at the beginning of this Article, it was on this point that Justice Blackmun faulted the Webster plurality for slighting the issues. ${ }^{75}$

Today, this jurisprudential debate seems much less urgent. Much of the debate has centered around whether or not any unwritten fundamental rights exist. Although that issue may continue to engage academics, as far as the Court is apparently concerned that philosophical battle is over.

Michael $H$. v. Gerald $D .^{76}$ illustrates the degree of judicial consensus on this point. The issue im Michael $H$. was whether or not California could deny all parental rights to a child's father on the ground that the mother was married to someone else when the child was born. ${ }^{77}$ Although he rejected the father's claim, Justice Scalia did not reject the concept of fundamental rights im his plurality opimion. Rather, he said, "[i]t is an established part of our constitutional jurisprudence that the term 'liberty' in the Due Process Clause extends beyond freedom from physical restraint."78 He quoted with approval Justice Powell's statement that "[o]ur decisions establish that the Constitution protects the sanctity of the family precisely because the institution of the family is deeply rooted in this Nation's history and tradition."79 Chief Justice Rehnquist joined Scalia's opinion in its entirety, while Justice O'Connor, in an opinion jomed by Justice Kennedy, wrote separately only to register her concern that Scalia's test for fundamental rights might be too narrow. ${ }^{80}$ Meanwhile, Justices Brennan, White, Marshall, and Blackmun dissented and argued that the father's fundamental right should have been recognized. ${ }^{81}$

75 See supra note 4 and accompanying text.

76109 S. Ct. 2333 (1989) (plurality opinion of Scalia, J., joined by Rehnquist, C.J., and O'Connor and Kennedy, JJ.).

77 Id. at 2336-37 (plurality opinion). Although phrased as a conclusive "presumption," the California statute was clearly substantive rather than procedural. Consequently, as Justice Scalia said in his plurality opinion, the issue was one of substantive due process. Id. at 2341 (plurality opinion).

78 Id. (plurality opinion).

79 Id. at 2342 (plurality opinion) (quoting Moore v. East Cleveland, 431 U.S. 494, 503 (plurality opinion of Powell, J.)).

80 See id. at 2346-47 (O'Connor, J., concurring in part).

81 See id. at 2349 (Brennan, J., dissenting, joined by Marshall and Blackmun, JJ.); id. at 2360-63 (White, J., dissenting, joined by Brennan, J.). It is unclear whether Justice White considered the case to involve substantive or procedural due process. 
In short, the Court in Michael $H$. was virtually unanimous in recognizing the existence of some constitutional protection for fundamental rights. Notably, even Justice Scalia, the most vehement critic of Roe on the Court, agreed on the existence of some substantive fundamental rights. Thus, Rehnquist's refusal in Webster to join the "great debate" about the existence of fundamental rights is entirely understandable - as far as the judiciary is concerned, that debate has been resolved $\mathrm{m}$ favor of their existence.

Since Roe was decided, it also has become somewhat less important that the abortion right be classified as fundamental. Even if abortion is a fundamental right, the decisions of the 1980's make it clear that abortions are still subject to reasonable regulation. And if it is not a fundamental right, abortion regulations are subject to rational basis review. Rational basis review used to be a guarantee of constitutionality, but that is no longer true. Rather, the Court has found the absence of a rational basis in cases dealing with such diverse subjects as group homes for the mentally retarded, ${ }^{82}$ property tax assessment, ${ }^{83}$ and the taxation of life insurance companies. ${ }^{84}$

If the Court considers the abortion right to be fundamental, abortion regulations will receive much more careful scrutiny even today, but we are no longer talking about the difference between extremely rigorous protection and no protection at all. ${ }^{85}$ Rather, we may be talking about the difference between requiring abortion regulations to be quite reasonable and only requiring them to be somewhat reasonable-not an insignificant difference, but not jurisprudentially earthshaking either. Indeed in Webster itself the four dissenters argued that the fetal testing statute would fail even the rational basis test unless given Rehnquist's construction. ${ }^{86}$ Consequently, Rehnquist may have been right in declining to debate whether abortion involves a fundamental constitutional right or a liberty interest.

82 City of Cleburne v. Cleburne Living Center, Inc., 473 U.S. 432 (1985).

83 Allegheny Pittsburgh Coal Co. v. County Comm'n, 109 S. Ct. 633 (1989).

84 Metropolitan Life Ins. Co. v. Ward, 470 U.S. 869 (1985).

85 Notably, the Supreme Court only sporadically has required a "compelling" interest in cases involving the right to privacy. See Schneider, State-Interest Analysis in Fourteenth Amendment "Privacy" Law: An Essay on the Constitutionalization of Social Issues, 51 Law \& Contemp. Probs. 79, 82-89 (1988).

86 See $109 \mathrm{~S}$. Ct. at 3070 (Blackmun, J., concurring in part and dissenting in part); id. at 3080 (Stevens, J., concurring in part and dissenting in part). 
Irrespective of labels, Chief Justice Rehnquist seems inclined to apply some type of reasonableness standard to abortion laws. If reasonableness were not required, it would be hard to understand his insistence on giving the Missouri statute a reasonable interpretationafter all, it would be constitutional even if it were unreasonable. Moreover, an important passage in his opinion suggests that unlimited regulation of abortion is not at all what he has in mind:

The dissent's suggestion that legislative bodies, in a Nation where more than half of our population is women, will treat our decision today as an invitation to enact abortion regulation reminiscent of the dark ages not only misreads our views but does scant justice to those who serve in such bodies and the people who elect them. ${ }^{87}$

Although admittedly this passage is guarded, it does mdicate that Rehnquist's views, properly understood, do not give carte blanche to state legislatures. ${ }^{88}$

If the existence of an abortion right no longer seems such a pressing question to the Justices, perhaps it is in part because the reasonableness framework is not likely to intrude unduly on the democratic process. Because this framework is clearly attuned to the positions of the general public and the legal community, the Court's role is likely to consist primarily of policing aberrational legislation. Public opinion polls consistently show that both attorneys and members of the public strongly oppose complete bans on abortions but favor reasonable regulation. ${ }^{89}$ In light of public opinion, the reasonableness framework does not present any major problem for state legislatures. Complete (or virtually complete) bans on abortion are unlikely in all

87 Id. at 3058 (emphasis added, citations omitted).

88 Ronald Dworkin recently has suggested that rational basis review would provide some protection for abortion rights. See Dworkin, The Future of Abortion, N.Y. Rev. of Books, Sept. 28, 1989, at 47, col. 1 .

89 In $1979,70 \%$ of the lawyers polled by the American Bar Association believed that abortion decisions should be left to the pregnant woman. Law Poll: Attitudes on Abortion and Firearms Control, 65 A.B.A. J. 1634 (1979). Three years later, after the Court's position regarding reasonable health regulations and the absence of a governmental duty to fund abortions became clear, a Harris survey found that the public opposed "a constitutional amendment to ban legalized abortions" by a 62-31 percentage margin. The Harris Survey, 1982, \# 63, August 9, 1982 (provided to one of the authors of this article and used in Nowak, Resurrecting Realist Jurisprudence: The Political Bias of Burger Court Justices, 17 Suffolk U.L. Rev. 549, 605 (1983)).

In 1986, only $22 \%$ of attorneys polled by the American Bar Association believed that Roe $v$. Wade should be overruled, although an additional $10 \%$ thought that further modification of 
but a relatively few states, and in addressing such bans the Court would be playing the relatively comfortable role of enforcing a national consensus against deviant local legislatures.

We certainly do not argue that the Supreme Court should follow the opinion polls, as it has sometimes been said to follow the election returns. But there is something notably academic about castigating a court decision as a brutal assault on denrocracy, when that decision is actually fairly close to what a large majority of the population wants. This convergence of the rule of reason and public opinion is one reason, we think, why the fundamental rights debate--and with it the question of whether Roe was illegitimate, as opposed to merely wrong-now seenis much less pressing to the Justices. Because the issue now is merely one of settling on the proper legal rule, rather than a basic issue of institutional legitimacy, a compromise solution seems nrore feasible.

Today, despite the fervor of the abortion debate, there is widespread agreenient on three major points. First, the state has a valid interest in protecting wonien's health. Second, it also has a strong interest in protecting fetuses later in the pregnancy. Third, abortions cannot be banned conipletely. All three points have overwhelming public support, and a majority of the Justices apparently accept thent.

the Roe principles was necessary. Law Poll: Lawyers Are at Odds with Reagan Administration on Abortion, 72 A.B.A. J. 42 (1986).

By the end of the decade, the support for the modified Roe principles and what we have termed the "reasonableness rule" of the 1980's was even stronger. In a 1989 Newsweek Poll only $17 \%$ of the public favored a total ban on abortions. McDaniel, The Future of Abortion, Newsweek, July 17, 1989, at 14, 15. In a poll done by the New York Times and CBS News after the 1989 Supreme Court decision in Webster, 68\% said "that even in cases where they might think abortion is wrong, the government has no business preventing a woman from having an abortion." The N.Y. Times, Aug. 3, 1989, at A18, col. 1. A later poll recorded similar results. The N.Y. Times, Sept. 29, 1989, at A1, col. 1. Both of these surveys demonstrate the strength of public support for the 1980's reasonableness approach to judicial review of abortion regulation, as opposed to the very strict approach that might have taken place if Justice Blackmun's view of Roe had prevailed. The surveys found that as many as $71 \%$ of adults favored requiring a woman under the age of 18 to receive her parents' consent before having an abortion. An Associated Press poll conducted in July 1989 showed that although adults support a woman's right to an abortion by a nearly 2-1 margin, $62 \%$ favored viability tests for a fetus after 20 weeks. Christian Sci. Monitor, July 25, 1989, at 8, col. 1.

The off-year elections in Virginia and New Jersey, following on the heels of the Webster decision, may indicate that staunch opponents of any right to have an abortion will face difficulties in upcoming elections. Both J. Marshall Coleman in Virginia and Jim Courter in New Jersey lost gubernatorial elections in which abortion rights were key issues. N.Y. Times, Nov. 9, 1989, at B14, col. 5 . 
In the furor of the abortion debate, however, it has been easy to lose sight of this common ground. Although this common ground admittedly leaves serious issues in dispute, a solid basis does exist for a reasonable resolution that can command widespread support.

\section{CONCLUSION}

If the Justices believe that the only choices with respect to abortion are a complete overruling of Roe $\boldsymbol{v}$. Wade or stringent judicial review of every medical regulation of abortion procedures, they may choose to dispatch abortion rights altogether. But there is another option: reject the strict review of abortion regulations and endorse a meaningful judicial role in preventing unreasonable legal barriers to women's access to abortions. Presented with this option, all but one or two of the Justices might endorse the continued judicial protection of a woman's right to control her reproductive system. This option has the advantage of roughly corresponding with public opinion, so that the Court rarely should have to invalidate legislation with strong majoritarian support.

The Supreme Court forged, although never acknowledged openly, the doctrinal basis for this middle ground in its decisions since the late 1970 's. It is a doctrine that our survey indicates is both easily understood and readily applied by the courts of appeals and the states' highest courts. With the fading of the judicial debate on fundamental rights, the Court is now free to turn from broad jurisprudential issues toward the more practical task of applying this reasonableness standard.

We do not claim prophetic powers. The Court's decisions of the last decade could provide the basis for announcing a workable judicial approach to abortion law. Whether the Justices will take advantage of that opportunity remains to be seen. 